\title{
Kvantumfizika és jog - Mire tanít a környezetvédelmi szabályozás kudarca?
}

\author{
környezetjog - ökológiai fenntarthatóság - klasszikus természetjog - \\ klasszikus hindu jog - természettudomány - tudat
}

Sokunk tisztában van azzal, hogy a természeti környezetért tett legkülönfélébb szintű (egyéni, nemzetközi) erőfeszítések dacára Földünk ökológiai állapota rendkívül aggasztó. Elég csak a klímaváltozásra vagy a biodiverzitás drámai csökkenésére gondolni. Azt már talán kevesebben tudjuk - vagy idáig nem is mertünk belegondolni -, hogy ez a helyzet a jelenlegi forgatókönyv mellett, a természettudományos elörejelzések alapján javulni nem fog, csak romlani. Ennélfogva egy elkerülhetetlen civilizációs hanyatlás, még rosszabb esetben összeomlás előtt állunk. Hogyan jutottunk ide? Mi az oka ennek a kétségbeejtő helyzetnek? Van-e egyáltalán remény társadalmi szinten, és ha van, min alapulhat?

Általában odáig valamennyien eljutottunk a szakirodalomban, hogy kimondjuk: az értékrendünk megváltoztatására, a fogyasztói „kultúra” lecserélésére lenne szükség. ${ }^{1}$ Csakhogy mire cseréljük? A környezeti korlátokat tiszteletben tartó, önfegyelmezett, szigorú lemondásokat igénylő ökologikus életmód a nagy többség számára egyáltalán nem vonzó. Bár tudjuk, hogy csak a szigorú önkorlátozás a megoldás, mégsem tesszük meg az ehhez szükséges lépéseket. Ralph Metzner ökopszichológus szerint ez azért van így, mert emberi társadalmunk jelenleg kóros állapotban van, szenvedélybeteg. ${ }^{2}$ A kényelem és kifinomult, illetve kevésbé kifinomult élvezetek függőjeként viselkedik. Ahogyan egy alkoholista vagy drogfüggő, ugyanúgy a jelenlegi társadalmunk sem tud lemondani az élvezetet nyújtó szerről, még akkor sem, ha ezzel önmaga vesztébe rohan. A jungi analitikus pszichológia egyik alapkoncepciója szerint az ilyen függőségnek, mentális betegségnek az oka, hogy elvesztettük kapcsolatunkat a transzcendenssel, s ezzel az élet értelmetlenné lett. ${ }^{3}$ Társadalmunk kóros viselkedése ezek szerint annak tudható be, hogy főként a

* Dr. Bányai Orsolya egyetemi adjunktus, Debreceni Egyetem Állam- és Jogtudományi Kar Agrárjogi, Környezetjogi és Munkajogi Tanszék, banyai.orsolya@law.unideb.hu.

AnTAL Z. László: Klímaparadoxonok. L’Harmattan, Budapest, 2015.

2 Metzner, Ralph: The Split Between Spirit and Nature in European Consciousness. Trumpeter, 1993/1. http:// trumpeter.athabascau.ca/index.php/trumpet/article/view/407/658 (2018. 05. 31.).

3 KoRoknal Bertalan-SzÉnYEl Gábor András: Test-lélek-szellem. Dr. Koroknai Bertalan összegyüjtött írásai. Alapítvány a Keresztény Szellemiségért, Budapest, 2017, 6; HANKISs Elemér: Kvantumtechnika és az élet 
materializmus világnézete hatja át. ${ }^{4}$ Modern jogrendszereink, amelyek szivacsként szívják magukba és adják ki magukból az uralkodó kulturális világnézetet, szintén ezt képviselik. Ennek egyik megnyilvánulása, hogy a jogrendszereink szinte teljesen elidegenedtek azoktól a természeti törvényszerüségektől, amelyek a valóságban ténylegesen szabályozzák univerzumunkban az életet. Életidegen jelleggel, mármár elhalt szervként illeszkednek az egész ökoszisztémába. Olyannyira torz a mai jogi környezet, hogy - a környezetjog egyes megnyilvánulásait kivéve - önmagában is akadályozza a mélyreható társadalmi változásokat, amely a természeti korlátokhoz való alkalmazkodást igényelné. Ha újból életet akarunk vinni belé, akkor vissza kell csatlakoztatni az „egészbe”. Ezt a nagyobb „egészet”, amiben jelenleg idegen testként éktelenkedik a pozitív jog, azok az univerzális természeti törvényszerüségek jelentik, amelyek a valóságban mindent áthatnak, beleértve az „Örök rendet”. Ahhoz, hogy helyreálljon a harmónia és egészség a természeti és társadalmi közegben, az ember alkotta jognak az „Örök rendet” is képviselő alapigazságokat kellene megtalálnia és azokat újból érvényesítenie. ${ }^{5}$

Jelen tanulmányban e mára sokak számára szinte láthatatlanná vált törvények kitapogatására vállalkozom. Mindezt különböző tudományterületek szakirodalomban publikált eredményeinek feltárásával, szintézisével végzem interdiszciplináris megközelítéssel. Ennek során a környezetjog keretei között kezdem, majd különböző természettudományok területén folytatom a gondolatmenetet, végül a jogtudomány határai mögé térek vissza, de egy, a kiindulóponthoz képest magasabb szintre. A téma jellegére tekintettel és a természettudományos eredmények megerősítése érdekében több helyen idézek a Bibliából, illetve a Bhagavad-gítából. ${ }^{6}$ Fontosnak tartom ugyanis, hogy híd épüljön tudomány és vallás közé, annak érdekében, hogy gyógyulhasson az a seb, amelyet e két terület között évszázadokig tátongó szakadék okozott.

\section{A környezetvédelmi szabályozás megbukott}

Már egy ideje foglalkoztat az a gondolat, hogy a környezetvédelmi szabályozás gyakorlatilag kudarcot vallott, de eddig ódzkodtam attól, hogy ezt egyértelmüen leírjam. Amikor azonban kezembe került Jan Laitos Why environmental policies fail

értelme. Magyar Tudomány, 2018/10, 1581. Az élet értelmetlenségét és a fogyasztói kultúra kapcsolatát vizsgálja Hankiss Elemér: Proletár reneszánsz. Helikon, Budapest, 1999.

4 A magyar nyelv értelmező szótára szerint a materializmus az a filozófiai irányzat, amely a tudattal és a gondolkozással szemben az anyag elsőbbségét hirdeti, és azt vallja, hogy az anyag a tudaton kívül és tőle függetlenül létezik, továbbá hogy a világ egységes anyagi felépítésủ és megismerhető. Arról, hogy mi az anyag, illetve hogy - annak ellenére, hogy a materialista világnézet alapja - mennyire nem tudjuk, hogy mi is az, lásd Vukıcs András: Materia Magica. Ars Naturae, 2012-2013/5-8. http://www.arsnaturae.hu/folyoirat_3_4/ vukics (2018. 05. 31.).

5 Hasonló eredményre jutott még Jan Laitos, Peter Burdon és Cormac Cullinan. Lásd a tanulmány utolsó pontjában.

6 Az indiai Védák egyik legfontosabb szentírása a Bhagavad-gíta (a továbbiakban: BG). A Védák, a tudás könyveiként ismert írások Földünk legrégebbi írásos emlékei. Tо́тн-SoмA László-DANKA Krisztina: A hinduizmus, brahmanizmus és a Védák lélekuniverzuma. In: Simon-Székely Attila (szerk.): Lélekenciklopédia. Világvallások lélekképzetei. L'Harmattan, Budapest, 2015, 415. 
címü könyve, megszünt bennem a tétovázás. A szerző a könyvében egyenesen kimondja, amit már sokan érezhetnek: a környezetpolitika és ezzel a környezetvédelmi szabályozás ${ }^{7}$ megbukott. ${ }^{8}$ Ezt azzal igazolja, hogy a nemzetközi tudományos közösség széles körben elismert tagjai - például Will Steffen kémikus, Johan Rockström és John Dearing földrajztudósok, Anthony Barnosky geológus, Peter Sale ökológus - között lényegében konszenzus van abban a tekintetben, hogy társadalmunk olyan mértékben károsította a Föld ökoszisztéma-rendszereit, hogy a bolygó hamarosan már nem tudja biztosítani az emberiség számára a létezési feltételeket. E tudósok szerint bizonyos korlátok átlépésével a Föld már nem lesz biztonságos az ember számára. Márpedig e korlátok közül néhányat már átléptünk (pl. klímaváltozás, biodiverzitás csökkenése), más korlátokat (pl. természeti erőforrások mint fémek, édesvíz, erdők kimerülése, légszennyezés, nitrogénkörforgás megváltozása stb.) pedig hamarosan átlépünk. A tudományos bizonyítékok szerint az emberiség globális fordulópont (tipping point) előtt áll, amelynek meghaladásával olyan ökológiai változásokkal számolhatunk, amelyekhez már nem tudunk alkalmazkodni. Ez vélhetően néhány generáción belül bekövetkezik. E veszélyt már 1992-ben jelezte 1700 vezető kutató azzal, hogy aláirták a "World Scientists Warning to Humanity" címet viselő dokumentumot. Ebben mindenkit figyelmeztettek, hogy lényegi változtatás hiányában az emberi társadalom a saját fennmaradását teszi kockára, a Föld ökoszisztéma-szolgáltatásainak összeomlása miatt. 2017-ben újabb figyelmeztetést adtak ki, amelyet immár több mint 15000 kutató írt alá 184 országból, megerősítve a korábbi nyilatkozatot és sürgetve a változtatást. ${ }^{9}$

Számos természettudományos visszajelzés igazolja, hogy a környezetpolitika és a környezetvédelmi szabályozás bizony megbukott, vagy legalábbis megbukni látszik. ${ }^{10}$ De használhatunk-e ilyen erős kifejezést? Egyáltalán lehet-e az ökológiai fenntarthatóság megvalósítása a szabályozás mércéje? ${ }^{11}$ Különösen ha belegondolunk, hogy előfordulnak részsikerek. Az indiai legfelső bíróság két eseti döntésének köszönhetően például bizonyíthatóan csökkent az indiai szent folyó, a Gangesz ipari eredetủ vízszennyezése és ezzel a csecsemőkori halálozások száma. ${ }^{12}$ Amikor ehhez hasonló eredményekkel találkozom, elgondolkodom rajta, hogy talán ami van, az is jobb, mint a semmi. A meglévő szabályozás is enyhíti a beteg tüneteit, még ha meg nem is gyógyítja. Csakhogy azáltal, hogy az éremnek van egy ilyen oldala, még

7 Laitos, Jan-Wolongevicz, Lauren Joseph: Why Environmental Laws Fail. William \& Mary Environmental Law and Policy Review, 2014/1, 1-52.

8 Laitos-Wolongevicz: i. m.; Laitos, Jan: Why Environmental Policies Fail. Cambridge University Press, Cambridge, 2017, 215. Lásd róla BÁnYAI Orsolya: A környezetpolitika múltja, jelene, jövője - gondolatok egy könyv alapján. Pro Futuro, 2017/3, 184-196.

9 World Scientists' Warning to Humanity: A Second Notice. BioScience, 2017/12, 1026-1028.

10 BÁnYAl (2017): i. m.; LÁng István-KereKes Sándor: Megalakult a Túlélés Szellemi Kör. Magyar Tudomány, 2013/1, 103-112.

11 FODOR László: A hatékonyság kérdése és a végrehajtási deficit a környezetvédelmi szabályozásban. In: Fodor László (szerk.): A környezetvédelmi jog és igazgatás hatékonyságának aktuális kérdései. LíciumArt, Debrecen, 2005, 17-53; Fodor László: Milyen környezetjogunk legyen? Természet Világa, 2003/10, 457-460.

12 Do, Quy-Toan-JoshI, Shareen-SToLPER, Samuel: Can environmental policy reduce infant mortality? Evidence from The Ganga Pollution Cases. Journal of Development Economics, 2018/4, 306-325. 
nem szűnik meg létezni a másik. Vagyis összességében, a kisebb-nagyobb sikerek ellenére a környezetvédelmi szabályozás jelenlegi formájában alkalmatlan az ökológiai fenntarthatóság megteremtésére. Már rég túllőttünk a Föld eltartóképességének határain, az összeomlás bármikor bekövetkezhet, sőt tulajdonképpen már zajlik is. ${ }^{13}$ Így látja ezt a Gaia-elmélet megfogalmazója, James Lovelock is: véleménye szerint még úgy 20 évig élvezhetjük azt az életformát, amelyben élünk. ${ }^{14}$ Mélyreható társadalmi, gazdasági és környezeti változás előtt állunk tehát, amit például egy, a közelmúltban publikált magyar jövőkutatás is megerősít. ${ }^{15}$ Sokak által kimondott radikális lépésekre ${ }^{16}$ lett volna szükség ahhoz, hogy a helyzetet megfelelően kezeljük, de erre nem volt meg a kollektív akarat, és talán már idő sincs rá.

Én is hasonló következtetésekre jutottam. Különösen amikor az energiafelhasználás csökkentésére ható nemzetközi, európai uniós és hazai szabályozást vizsgáltam, ahol egyértelmủen láthatóvá vált: nincsenek meg bennük azok az elemek, amelyek ahhoz szükségesek, hogy a társadalom egyfajta önkorlátozással vissza tudjon térni az ökológiai korlátok mögé. ${ }^{17}$ Pedig az energiafelhasználás mennyisége jelentős faktor az emberi társadalom ökológiai lábnyomában, így ha az csökkent volna, vele párhuzamosan az ökológiai lábnyom is zsugorodott volna. De továbbmegyek. Az állati termékek fogyasztásának drasztikus visszaszorításával (az energiafelhasználáshoz képest) még egyszerübb módja is kínálkozott volna az ökológiai lábnyom számottevő csökkentésének. Széles körü szakirodalom támasztja alá ugyanis, hogy a hús, tojás és tejtermékek fogyasztása még az energiafelhasználáshoz, energiatermeléshez képest is jelentősebb környezeti terhelést okoz. ${ }^{18}$ Ennek visszafogásával - különösen a gazdaságilag fejlett országokban, ahol amúgy is túlfogyasztás jellemző, annak minden káros egészségügyi következményével - értelemszerüen

13 Meadows, Donella-Randers, Jorgen-Meadows, Dennis: A növekedés határai harminc év múltán. Kossuth, Budapest, 2005, 23; Cullinan, Cormac: Wild Law. Siber Ink, Cape Town, 2011, 65. A Living Planet Report 2016 adatai szerint az emberi társadalom 60\%-kal haladta már meg a Föld biokapacitását. https://www. footprintnetwork.org/content/documents/2016_Living_Planet_Report_Lo.pdf (2018. 05. 31.).

14 Decca, Aitkenhead: James Lovelock: 'Enjoy life while you can: in 20 years global warming will hit the fan'. The Guardian, 1 March 2008. https://www.theguardian.com/theguardian/2008/mar/01/scienceofclimatechange. climatechange (2018. 05. 31.).

15 Hideg Éva-Mıнók Barbara-GÁspÁr Judit-Schmidt Péter-MÁrton András-BÁldı András: Környezeti jövőkutatás: Magyarország 2050. Magyar Tudomány, 2018/5, 714-728.

16 KEREKES Sándor: A szenvedélyek féken tartása, avagy a fenntartható kapitalizmus? Közgazdaság, 2016/2, 65-76; TAKÁCS-SÁNTA András-BóDı Balázs: Tikopia társadalma, amely elkerülte a közlegelők tragédiáját. Társadalomtudományi Szemle, 2016/3, 91-104; BÁNYAl Orsolya: Energiajog az ökológiai fenntarthatóság szolgálatában. DELA, Debrecen, 2014; LENGYEL Attila: A fenntarthatósági indikátorok térbeli diszkontálása. Területi Statisztika, 2017/2, 185; GRUBLER, Arnolf (et al): A low energy demand scenario for meeting the $1.5^{\circ} \mathrm{C}$ target and sustainable development goals without negative emission technologies. Nature Energy, 2018/6, 515-527; DiAmond, Jared: Összeomlás. Typotex, Budapest, 2009; VIDA Gábor: Fenntarthatóság és a tudósok felelőssége. Magyar Tudomány, 2007/12, 1600-1606; VIDA Gábor: Klímahelyzet 2016. Magyar Tudomány, 2017/6, 645-651; LeAdLey, Paul (et al): Biodiversity Scenarios: Projections of 21st century change in biodiversity and associated ecosystem services. Secretariat of the Convention on Biological Diversity, Montreal. Technical Series no. 50, 2010, 3. https://www.cbd.int/doc/publications/cbd-ts-50-en.pdf (2018. 07. 12.).

17 BÁNYAl (2014): i. m.

18 DomBI Mihály-KARCAGI-KovÁts Andrea-BAUERnÉ GÁtHY Andrea: Vacsora tálalva! Természeti erőforrások és az élelmiszer-fogyasztás. Magyar Tudomány, 2017/11, 1455-1467. 
szintén csökkenthetö lenne/lett volna az ökológiai lábnyom. Az e csökkentésben rejlő potenciál a szakirodalom szerint $34-60 \%$ körül mozog. ${ }^{19} \mathrm{Az}$ állati termékeket jelentősen csökkentő étrend ráadásul összhangban lenne az egészségügyi ajánlásokkal is. ${ }^{20}$ Mindezek ellenére az állati termékek fogyasztásának, termelésének visszafogására irányuló szabályozás igen ritka. ${ }^{21}$ Így nem meglepő, hogy a jelenlegi jogi szabályozás nemcsak alkalmatlan az ökológiai krízis kezelésére, de azzal, hogy magában foglalja és érvényesíti azt a helytelen értékrendet (pl. fogyasztói kultúra, versenyképesség), ${ }^{22}$ amire korunk társadalma épül, önmagában akadályozza a mélyebbre ható és gyógyulást elősegítő változtatásokat. ${ }^{23}$

Visszatérek ahhoz a kérdéshez, hogy lehet-e egyáltalán az ökológiai fenntarthatóság biztosítása a szabályozás sikerességének mércéje. Álláspontom szerint igen. Ahogyan Fodor László írja, „,a környezetvédelmi szabályozás hatékonyságának első számú viszonyítási alapja (indikátora) az, hogy hogyan alakulnak a környezethasználatok, illetve a környezet állapota". ${ }^{24}$ A környezetvédelmi szabályozást a 20 . század közepén éppen az hívta életre, hogy felismerték az emberi tevékenység káros környezeti hatásait. Olyan jelentős hatással vagyunk ugyanis a Föld ökoszisztémájára, hogy a földtudományban külön földtörténeti korszakként (antropocén) kezdik emlegetni ezt az időszakot. ${ }^{25}$ Vagyis nemhogy lehetséges, de a környezet állapota kell, hogy legyen az alapvető viszonyítási pont, amikor a szabályozást értékeljük.

Összegezve tehát, az emberi tevékenység olyan mértékben károsította a Föld ökoszisztéma-rendszereit, hogy nagy valószínűséggel bolygónk hamarosan már nem tudja biztosítani az emberiség számára a biztonságos létezési feltételeket. Ebből kifolyólag kijelenthetjük, hogy ennek a helyzetnek az elkerülésére létrehívott legkülönfélébb jogi szabályozó eszközök kudarcot vallottak. A szabályozás feltehe-

19 VetönÉ Mózner Zsófia-Csutora Mária: Designing Lifestyle-specific Food Policies Based on Nutritional Requirements and Ecological Footprints. Sustainability: Science, Practice \& Policy, 2013/9, 47-59.

20 Dombi-Karcagi-Kováts-Bauerné Gáthy: i. m.

21 ZAYLíA, Jessica Leigh: Mass meat consumption, human rights, and animal welfare: an alternative appeal to limitative federal legislation. San Joaquin Agricultural Law Review, 2009-2010/1, 251-277; MıLman, OliverLeAVENWORTH, Stuart: China's plan to cut meat consumption by $50 \%$ cheered by climate campaigners. The Guardian, 20 June 2016. https://www.theguardian.com/world/2016/jun/20/chinas-meat-consumptionclimate-change (2018. 12. 05.).

22 GYuLAl Iván: Kérdések és válaszok a fenntartható fejlődésről. Magyar Természetvédők Szövetsége, Budapest, 2008, 11.

23 BánYal Orsolya: A jövő reménységei - a valóban fenntartható települések. Miskolci Jogi Szemle, 2017/2, 91-104; BeRRY, Thomas: 'Legal Conditions for Earth's Survival'. In: Tucker, Mary-Evelyn (ed.): Evening Thoughts: Reflections on Earth as Sacred Community. Sierra Club, San Francisco, 2006, 107; WeSTERLUND, Staffan: Theory for Sustainable Development; Towards or Against? In: Bugge, Hans Christian-Voigt, Christina (eds.): Sustainable Development in International and National Law. Europa Law Publishing, Amsterdam, 2008, 63; Steinberg, Paul F.: Who Rules the Earth? How Social Rules Shape Our Planet and Our Lives. Oxford University Press, Oxford, 2015; Bosselmann, Klaus: Grounding the rule of law. In: Voigt, Christina (ed.): Rule of Law for Nature: New Dimensions and Ideas in Environmental Law. Cambridge University Press, Cambridge, 2013, 91; Fodor (2005): i. m., 18; Cullinan (2011): i. m., 65.

24 FODOR (2005): i. m., 18.

25 VIDA Gábor: Honnan hová Homo? Az Antropocén korszak gondjai. Semmelweis, Budapest, 2012. 
tően nemigen fog változni. ${ }^{26}$ Tehát igenis használhatjuk a fenti erős kifejezést a jelenség megfogalmazására. Csak ennek elismerése után mehetünk mélyebbre, hogy megértsük a kudarc okait, és hogy új utakat keressünk. Feltehetően a mélyreható változásokkal járó hanyatlás keretében egy viszonylag nagy területen hosszú időre drasztikusan lecsökken a lakosok száma, a politikai, gazdasági és társadalmi szerkezet pedig veszít eddigi komplexitásából. ${ }^{27}$ Talán $50-150$ év elteltével azonban egy megújult társadalom kezdhet mindent az elejéröl. Éppen ezért lenne fontos megérteni a probléma okait, hogy azok a jövőben már elkerülhetők lehessenek.

\section{A kudarc okai}

A környezetjogot művelök többsége tagadja, hogy az ökológiai válság megoldása mély, rendszerszintủ változtatást igényelne. E közösség kritikái egy állam, esetleg egy-egy program hibáira fókuszálnak csupán. ${ }^{28} \mathrm{~A}$ szabályozási kudarc okai tekintetében azonban a szakirodalomból viszonylag sokszínủ kép bontakozik ki. Eszerint a sikertelenség okai több szinten nyilvánulhatnak meg: környezetjogi, környezetpolitikai, környezeti etikai és végül ontológiai szinten. A különböző szintű magyarázatok között ugyanakkor áthallások vannak, tehát korántsem olyan éles az elhatárolás, mint amilyennek elsőre tünhet. Nézzük ezeket sorra. ${ }^{29}$

A jogi szakirodalomban Westerlund két okkal magyarázza, hogy a jogi szabályozás miért nem alkalmas a környezeti fenntarthatóság biztosítására. Egyrészt azzal, hogy „a nemzetközi és EK jogrendszer belsöleg nem konzisztens (egymással ellentétes célokat tükröznek, illetve a fenntartható fejlődés nincs a legfontosabb prioritások között). Másrészt túlzottan rugalmatlanok ahhoz, hogy alkalmazkodjanak bármihez, ...azzal a céllal, hogy az ökológiai fenntarthatóságot megteremtsék." 30 A jogrendszer inkoherenciáját és a legitim célok egymást kioltó jellegét az energiafelhasználás csökkentésére irányuló szabályozás tekintetében magam is megfogalmaztam már korábban. ${ }^{31}$ Ami pedig a rugalmatlanságot illeti, Jan Laitos is a hatályos (környezet)jog egyik komoly problémájaként említi, együtt annak túlbonyolítottságával. Ez a merevség és bonyolultság véleménye szerint nem összeegyeztethető a természeti törvényszerüségekkel, amelyeket többek között az egyszerüségre törekvés és a dinamizmus jellemez. ${ }^{32} \mathrm{Ez}$ a gondolat továbbvezet minket egy újabban egyre nagyobb teret kapó tudományos elmélethez (Earth Jurisprudence), miszerint

26 LÁNYI András: Az ember fáj a földnek. Utak az ökofilozófiához. L'Harmattan, Budapest, 2010, 20; CULLINAN (2011): i. m., 65; GRUHL, Herbert: Himmelfahrt ins Nichts. Der geplünderte Planet vor dem Ende. Langen Müller, München, 1992; Romı,, Friedrich: Itt a végünk? Az ökológiai katasztrófa és annak háttérokai. Ars Naturae, 2010/1-2. http://arsnaturae.hu/folyoirat_1_2/romig (2018. 07. 12.).

27 DiAmond: i. m., 15.

28 Wood, Mary Christina: Nature's Trust: Environmental Law for a New Ecological Age. Cambridge University Press, Cambridge, 2014, 10.

29 Plumwood, Val: The Ecological Crisis of Reason. Routledge, New York, 2002.

30 Idézi BÁNDı Gyula: A fenntarthatóság értelmezésének egyes jogi szempontjai. MTA Doktori értekezés, Budapest, 2013, 148.

31 BÁnYAI (2014): i. m.

32 LAITOS (2017): i. m. 
a kudarc oka, hogy a jogrendszer nincs összhangban azokkal a természeti törvényekkel, amelyeket a modern tudományok is megfogalmaznak. ${ }^{33}$ Cormac Cullinan szavaival élve „a környezetvédelmi jog kudarcának az az oka, hogy az ember önmagát kivételes helyzetbe helyezi, úgy véli, hogy nem része a természetnek, rá nem vonatkoznak a természet törvényei, azokat nem veszi komolyan. A jogrendszer ennek hatására elvesztette kapcsolatát a Föld rendszereivel." ${ }^{44}$ Ezzel a gondolattal teljesen egyetértek. Azzal kapcsolatban, hogy miben nyilvánulnak meg a természeti törvények, amelyekhez a jogrendszereknek ${ }^{35}$ - vagy a klasszikus természetjogi terminus szerint az ember alkotta jognak - igazodniuk kell, rámutatok egy általam „Örök rendként” aposztrofált igazságra is. Álláspontom további magyarázatára a későbbiekben kerül sor.

A környezetpolitikai diskurzusban jellemzően a következő okokkal magyarázzák az ökológiai krízist. ${ }^{36}$ Vannak, akik a probléma forrását az ipari kapitalizmusban, ${ }^{37}$ mások a konzumerizmusban, ${ }^{38}$ a túlnépesedésben, ${ }^{39}$ a technológiában, ${ }^{40}$ a patriarchátus eszméjében, ${ }^{41}$ a rasszizmusban, ${ }^{42}$ a modernizmusban, ${ }^{43}$ esetleg az antropocentrizmusban ${ }^{44}$ látják. Lányi András szerint „az ökológiai politika azért maradt ennyire hatástalan, mert programja ...rendszeridegen: tökéletesen összeférhetetlen a modern ipari társadalmak rendjével" ${ }^{45}$ Természetesen az elöbb felsorolt okok csupán címkék. Az okokat kutatók a legtöbb esetben árnyalják kijelentéseiket, így azok jellemzően összetett tartalmat hordoznak. Többek között ez is az oka annak, hogy a látszattal ellentétben azért mégsem ennyire heterogén a kép.

A környezetetika tudománya az embernek a természeti (nem emberi) környezetéhez füződő erkölcsi kapcsolatát, valamint e kapcsolat értékét, morális státuszát tanulmányozza. ${ }^{46}$ Ezen a területen a legtöbben egyetértenek abban, hogy a válság

33 Burdon, Peter: Earth Jurisprudence: Private Property and the Environment. Routledge, New York, 2015.

34 Cullinan, Cormac: The Rule of Nature's law. In: Voigt, Christina (ed.): Rule of Law for Nature: New Dimensions and Ideas in Environmental law. Cambridge University Press, Cambridge, 2013, 100.

$35 \mathrm{~A}$,jogrendszer" kifejezést itt véleményem szerint használhatjuk széles értelemben, ami egyaránt magában foglalja a főbb „nyugati” és ázsiai jogrendszereket.

36 Burdon (2015): i. m.

37 Foster, John Bellamy-CLARK, Brett-YoRk, Richard: The Ecological Rift: Capitalism's War on the Earth. Monthly Review Press, New York, 2010.

38 Alexander, Samuel (ed.): Voluntary simplicity: The poetic alternative to consumer culture. Stead \& Daughters, Whanganui, 2009.

39 Ehrlich, Paul R.-Ehrlich, Anne H.: Population, Resources, Environment. Issues in Human Ecology. Freeman, San Francisco, 1970.

40 Borgmann, Albert: Technology and the Character of Contemporary Life: A Philosophical Inquiry. University of Chicago Press, Chicago, 1984.

41 Merchant, Carolyn: The Death of Nature: Women, Ecology, and the Scientific Revolution. Harper and Row, San Francisco, 1980.

42 Westra, Laura-Lawson, Bill E. (eds.): Faces of Environmental Racism: Confronting Issues of Global Justice. Rowman \& Littlefield, New York, 1995.

43 COATES, John: Exploring the Roots of the Environmental Crisis: Opportunity for Social Transformation. Critical Social Work, 2003/1. http://www1.uwindsor.ca/criticalsocialwork/exploring-the-roots-of-the-environmentalcrisis-opportunity-for-social-transformation (2018. 12. 05.).

44 Ehrenfeld, David W.: The Arrogance of Humanism. Oxford University Press, Oxford, 1981.

45 LÁNYI (2010): i. m., 20.

46 Tóth I. János: Fejezetek a környezetfilozófiából. JATE-Press, Szeged, 2005, 123. 
oka az az emberi világnézet, amely egyfelől megkülönbözteti az embert az őt körülvevő világtól, a természettől (dualitás), másfelől úgy véli, hogy az ember a természet fölött áll, uralkodhat azon (dominancia). ${ }^{47}$ Véleményük szerint lényegében ez a dualista és emberközpontú felfogás vezetett a természet lealacsonyításához és kizsákmányolásához.

Végül a válságjelenség magyarázatának van egy lételméleti szintje is, amely lényegében a probléma legmélyebb gyökeréig vezet, és kiegészíti az előbb felsorolt okokat. Annak kifejtéséhez, hogy mit is értek ezalatt, segítségül hívom Lányi András párhuzamát, aki az egész környezeti krízist Oidipusz tragédiájához hasonlítja. Lányi arra a megállapításra jut, hogy az „ökológiai válság egy globális civilizáció tragikus önfélreértésének következménye” ${ }^{48}$ Vagyis, miként Oidipusz, a globális civilizációnkat alkotó egyének döntő többsége sem ismeri önmagát. Ennek következtében, amikor olyan próbatétel előtt áll, mint Oidipusz a Szfinx talánya kapcsán, ugyanúgy rossz döntést fog hozni, mint a tragikus hős. Oidipusz ugyanis rosszul oldotta meg a rejtvényt, és ezt még csak nem is látta, mindaddig, amíg nem szembesült a Théba városát sújtó dögvésszel. „A járvány addig tart, amíg a Nagy Rejtvényfejtő meg nem fejti önnön létezése rejtélyét. [...] De mit is jelent tudni, hogy kik vagyunk valójában?"49 Amikor erre a kérdésre helyes választ adunk, akkor fog megszünni a „dögvész”, amit a nyakunkra hoztunk. Vagyis a krízis legmélyebb szinten ontológiai gyökerü.

\section{A környezeti krízis ontológiai gyökere}

Az a kérdés, hogy kik vagyunk valójában, mindig is foglalkoztatta az embert. A választ egyfelől a szentírások kinyilatkoztatásai alapján, másfelől a 18. századi felvilágosodás térnyerésének köszönhetően a természettudományok következtetései alapján kapta. Azt, hogy kik is vagyunk valójában, a 19. századig a vallási tanítások határozták meg. A hitrendszerek döntő többsége szerint az ember lényegét egy transzcendens ${ }^{50}$ természetü lélek (héb. ruah, gör. pneuma, szanszkr. atman) vagy a magyar szóhasználatban elterjedt „szellem” alkotja. ${ }^{51}$ Ezzel szemben a természettudományos eredmények az embert „materializálták”. Így mára az uralkodó tudományos álláspont szerint a lélek lényegében maga az agy (pontosabban szólva

47 Többek között Arne Naess, Thomas Berry, Ralph Metzner, John Livingston, Murray Bookchin, Cormac Cullinan.

48 LÁNYI András: Oidipusz, avagy a természetes ember. Liget, 2014/12. http://www.liget.org/cikk.php?cikk id $=3047$ (2018. 06. 22.).

49 LÁNYI (2014): i. m.

50 A „transzcendens” fogalmát itt a hagyományos értelemben, vagyis „természetfölötti” értelemben használom, de a tanulmány többi részében azt értem alatta, ami túl van a téridő-kontinuumon.

51 SıMON-Székely Attila: A lélek mítoszokban és vallásokban. Animula, Budapest, 2008, 7. Amikor a továbbiakban az ember eredeti transzcendens természetére utalok, mind a lélek, mind a szellem kifejezést használni fogom. 
annak biológiai folyamatai), ${ }^{52}$ vagy más megközelítésben a psziché. ${ }^{53}$ Ez a materialista felfogás a darwini evolúcióelmélet elfogadásával és oktatásával párhuzamosan széleskörüen elterjedt a társadalomban. A lelket a tudományok megfosztották szentségétől és - hasonlóan a természethez - egyszerüen gépezetté redukálták. Ezt a jelenséget úgy is megfogalmazhatjuk, hogy a szubjektumot a téridő-kontinuumon belülre korlátozták. Nem meglepő egybeesés, hogy ember és természet elidegenedésének kezdete is erre az időszakra tehető.

Márpedig annak ismerete, hogy milyen az ember lényegi természete (azaz transzcendens vagy immanens), ${ }^{54}$ nem csupán filozófiai kérdés, a helytelen azonosítás ugyanis komoly gyakorlati következményekkel jár. Ez a legkönnyebben a következő hasonlattal szemléltethető. Képzeljük el, hogy egy ember egy autóban ül, és abban a téves felfogásban él, hogy ő maga az autó. Ez egyfelől - kívülről nézve a tévedést nyilvánvaló őrültség. Másfelől, az ember nem fog jóllakni azzal az energiahordozóval (üzemanyag, olaj), amely a gépkocsi müködtetéséhez kell. A kocsi müködik tőle, de az ember közben továbbra is éhezik, mert elfelejtett önmagáról gondoskodni. Nem beszélve arról, hogy az ember életéhez sokkal több kell, mint pusztán üzemanyag. Így lehetetlen, hogy az ember elégedett legyen egy autó-léttel. Ugyanakkor, ha már tudja magáról, hogy ő valójában ember, az emberi céljai megvalósítása érdekében eszközként használhatja az autót. Így tehát kimondhatjuk, hogy ha az ember valójában transzcendens természetü, és ennek ellenére immanensnek gondolja magát, akkor a lélek szenved. Innen eredhet az elidegenedés a természettő| ${ }^{55}$ és más emberektöl egyaránt. ${ }^{56}$

Úgy vélem tehát, hogy miként Oidipusz a fenti hasonlatban, úgy a mai kor embere is tévesen azonosította be magát, és innen ered a „dögvész”, azaz a környezeti, társadalmi krízis. A szakirodalomban sokan jutnak hasonló következtetésre, és egyre többen állítják, hogy az ökológiai fenntarthatóság nem tudományos-technikai, hanem spirituális ${ }^{57}$ probléma. ${ }^{58}$ Egy környezetpszichológiai kutatás például kimutatta,

52 Szalal Miklós: Ateizmus, naturalizmus, materializmus. In: Simon-Székely Attila (szerk.): Lélekenciklopédia 2. Gondolat, Budapest, 2016, 127.

53 Simon-SzÉKELY Attila: Általános, kognitív és biológiai pszichológia. In: Simon-Székely Attila (szerk.): Lélekenciklopédia 2. Gondolat, Budapest, 2016, 146.

54 A tanulmányban abban az értelemben használom, hogy téridő-kontinuumon belüli.

55 Az állatok, növények, sőt maga a Föld is ontológiai értelemben, lényegüket tekintve ugyanolyan szellemi létezők, mint az ember. Lásd BG 2.30., Biblia Prédikátorok könyve 3:19. Tény azonban, hogy az állatok lelkéről inkább az „apokrif”, azaz az egyház által hivatalosan nem jóváhagyott keresztény irodalomban olvashatunk. Például: „Aki az állatok lelkét szentségteleníti, az a saját lelkét szentségteleníti” (Hénoch titkainak könyve 59:1). Lásd GÁNóczy Sándor: Állati ember - emberi állat. Magyar Tudomány, 2014/5, 576-586. A természettudományos elméletek közül a biocentrizmus és a pánpszichista „integrált információelmélet” tekint többek között az élölényekre úgy, mint amelyeknek a tudata az emberhez hasonló természetü. Lásd http://integratedinformationtheory.org/.

56 ZsÁKAl Annamária: Biológia. In: Simon-Székely Attila (szerk.): Lélekenciklopédia 2. Gondolat, Budapest, 2016, 259.

57 „Spiritualitás” alatt a következőt értem: az embereknek mindazon különféle útkeresése, amely az élet azon mély értelmének megértését szolgálja, amely összeköti őket minden élőlénnyel és Istennel vagy másképp a Végső Valósággal. Lásd Zsolnaı László: Spirituality, Ethics and Sustainability. In: Zsolnai László (ed.): The Spiritual Dimension of Business Ethics and Sustainability Management. Springer, Zürich, 6.

58 Lengyel: i. m., 185; Zsolnal: i. m.; Suvorov, Nickola-Suvorova, Iryna: The Concept of Holistic and Sustainable Development Based on Harmony. European Journal of Sustainable Development, 2015/4, 227-234; GoRE, 
hogy pozitív korreláció mutatkozik a belső lelki fejlődésre fókuszáló világnézettel (intrinsically oriented worldviews) rendelkező emberek és a környezetvédelmi attitủd, illetve életmód között. Míg negatív korreláció figyelhető meg a pénzre fókuszáló szekuláris materialista világnézettel (extrinsically oriented worldviews) rendelkező emberek és a környezetbarát tettek között. ${ }^{59} \mathrm{~A}$ lelki vezetők vagy a környezetjogra is nagy hatást gyakorló ökoteológus Thomas Berry is azt hangsúlyozzák, hogy a környezeti problémák a spirituális szemlélet hiányából erednek. ${ }^{60}$ Összességében azt mondhatjuk, hogy a környezeti krízisnek, habár okai sokrétüek, mindenképpen van egy téves önazonosságból származó, ontológiai gyökere is.

\section{A modern tudomány és a transzcendens tudat viszonya}

A felvetés, miszerint a környezeti problémák visszavezethetök a téves önazonosságra, feltételezi, hogy lényünk valójában transzcendens természetü. Ahhoz, hogy e prekoncepcióra a továbbiakban építkezhessem, szükséges annak tudományos megerősítése is. A tudományos életben a többség még azt a szemléletet képviseli, hogy létezik egy olyan, szubjektumtól független objektív valóság, amely képes hiteles választ adni arra az alapkérdésre, hogy kik vagyunk valójában. Tehát a mainstream tudomány az ember immanens természetét feltételezi. Sokan felvetik azonban, hogy a modern tudomány legújabb eredményei alapján úgy tủnik, paradigmaváltás zajlik. ${ }^{61}$ Mint látni fogjuk, egyre többen fogadják el azt a tényt, hogy szubjektumtól független objektív valóság nem létezik. Tehát a hagyományos materializmus falai mintha kezdenének leomlani. Az alábbiakban az ezen állítást igazoló eredményeket tekintem át.

Kutatásaim során arra lettem figyelmes, hogy több tudományterület (például részecskefizika, tudatkutatás, kozmológia, biológia, pszichológia) kutatási következtetései is ugyanabba az irányba mutatnak. Ezek az eredmények a szubjektum

Al: Earth in the Balance: Ecology and the Human Spirit. Houghton Mifflin, New York, 1992; GÁtHY AndreaKutı István-SzaBó Gábor: Fenntartható fejlődési politikák és stratégiák az Európai Unióban. In: Bulla Miklós-Tamás Pál (szerk.): Fenntartható fejlődés Magyarországon. Új Mandátum, Budapest, 2006, 179; Huesemann, Michael-Huesemann, Joyce: Techno-Fix: Why Technology Won't Save Us or the Environment. New Society Publishers, Gabriola Island, 2011; HoRvÁTH Róbert: A tudatökológia alapelvei. http://arsnaturae. hu/tudatokologia/horvath_alapelvek (2018. 05. 12.).

59 Hedlund-de Witt, Annick-de Boer, Joop-BoersemA, Jan J.: Exploring inner and outer worlds: A quantitative study of worldviews, environmental attitudes, and sustainable lifestyles. Journal of Environmental Psyshology, 2014/1, 40-54.

60 Gottlieb, Roger (ed.): This sacred Earth. Religion, nature, environment. Routledge, New York, 2003; Vaughan-Lee, Llewellyn (ed.): Spiritual ecology. The cry of the Earth. The Golden Sufi Center, Point Reyes, 2013; Sivarama Swami: A környezetvédelem gyökerei. Tattva, 2016/1, 17-21; NASR, Seyyed Hossein: The need for a sacred science. Taylor\&Francis, Richmond, 2005; NeRIL, Rabbi Yonatan: The Spiritual Roots of the Environmental Crisis. Canfei Nesharim, 2014. http://canfeinesharim.org/the-spiritual-roots-of-theenvironmental-crisis/ (2018. 07. 04.); BerRY, Thomas: The new story. In: Fabel, Arthur-Donald, John (eds.): Teilhard in the $21^{\text {th }}$ century: The emerging spirit of Earth. Orbis Books, Maryknoll, 2003, 77-88, 86.

61 Dossey, Larry: Consciousness and TDVP: Welcome to a New World. Explore, 2017/6-7, 233-237; LÁszLó Ervin: The science and Akashic field. An integral theory of everything. Inner Tradition, Rochester, 2014, 16; HANKISS (2018): i. m. 
természetére, valamint a tudat és anyag ${ }^{62}$ viszonyára vonatkoznak. Ezen a ponton felmerülhet a kérdés, hogy mi köze a léleknek a tudathoz? Ennek megválaszolása fontos feltétele annak, hogy a következő fejezet érthetővé váljon. A tudat az élőlény léttünete. ${ }^{63} \mathrm{~A}$ lélek létét a tudat úgy bizonyítja, mint ahogy a nap létét a napsugár, illetve a fény. ${ }^{64}$ Ennélfogva a tudat és a lélek természete hasonló. Tehát ha egzakt tudományos eredményeket kapunk a tudat természetére, akkor ezek a lélek természetére ugyanúgy igazak. Most tehát nézzük a modern tudomány egyes eredményeit.

\subsection{Kvantumfizika}

Ezen a területen a 20. század első fele több olyan forradalmi áttörést hozott (általános és speciális relativitáselmélet, kvantumtechnika), amelyek hatására az addigi abszolút kategóriákban gondolkodó klasszikus fizikába bekerült a relativitás (például a téridő összefonódása). ${ }^{65}$ A relativitáson túl egy új, a hagyományos fizikában igencsak szokatlan gondolat is megjelent. Nevezetesen az, hogy a mikrorészecskék amúgy is misztikus, józan ésszel nehezen felfogható világában egyes jelenségek megmagyarázásához elkerülhetetlenné vált annak felvetése, hogy a megfigyelönek szerepe van a részecskék viselkedésének alakulásában. Az elemi részecskék ugyanis megfigyelés hatására (observer effect) másként viselkednek. A 20. század „legszebb kísérletének” tartott ún. kétréses kísérlet ${ }^{66}$ és annak továbbfejlesztett változatai igazolják, hogy az elemi részecske (például az elektron, foton) megfigyelés hatására pontszerủ részecskeként, nem hullámként viselkedik (hullámfüggvény öszszeomlása/a szuperponált állapot megszűnése). ${ }^{67} \mathrm{Az}$ egyik ilyen továbbfejlesztett változatnál, az ún. Wheeler késleltetett-választásos kísérletnél a részecske megfigyelése (mérése) utólagos volt. A kísérlet azt igazolta, hogy a részecske viselkedését az a döntés határozza meg, hogy a mérés egyáltalán megtörténik-e. ${ }^{68} \mathrm{~A}$ kísérle-

62 Az „anyag” fogalmát a tanulmányban abban az értelemben használom, hogy mindaz, ami nem transzcendentális. Vagyis megkülönböztetek transzcendens tudatot és immanens anyagot. A Bhagavad-gíta az „anyagi természet” (szanszkr. prakrti) kifejezést használja, amikor az általam „anyagnak” mondott valóságra utal, míg a „tudatra” a „megfigyelő”, illetve az „élvező” kifejezést is használja (szanszkr. purusa).

63 Azt, hogy milyen értelemben használom a „tudat” kifejezést, a 4.2. (Tudatkutatás) alpont bevezető soraiban fejtem ki.

64 A Bhagavad-gíta a nap és a napfény példájával világít rá a tudat és a lélek kapcsolatára. Ahogyan a nap szilárdan egy helyben állva bevilágítja a környező univerzumot, úgy ragyogja be tudatával az egész testet a szívben lakozó parányi lélek. Így tehát a lélek létét a tudat bizonyítja, mint ahogy a nap létét a napsugár, illetve a fény. A tudat tehát az élőlény léttünete. Bhaktivedanta Swami Prabhupada, A.C.: A Bhagavad-gíta úgy, ahogy van. Bhaktivedanta Book Trust, Grödinge, 2016, 594.

65 Rockenbauer Antal: A modern fizika dilemmái. Haladás vagy zsákutca? A fizika kalandja, 2015. július 22. https://afizikakalandja.blog.hu/2015/07/22/a_modern_fizika_dilemmai (2018. 07. 29.).

66 Tonomura, Akira: The double-slit experiment. Physics World, 1 September 2002. https://physicsworld.com/a/ the-double-slit-experiment/ (2018. 07. 29.).

67 Anyagi részecskeként viselkedik és nem hullámként, miközben megfigyelés nélkül ugyanabban a szituációban hullámként viselkedett. Quantum Theory Demonstrated: Observation Affects Reality. EurekAlert!, 26 February 1998. https://www.eurekalert.org/pub_releases/1998-02/WI-QTDO-260298.php (2018. 07. 29.).

68 JACQUES, Vincent (et al): Experimental Realization of Wheeler's Delayed-Choice Gedanken Experiment. Science, 2007/5814, 966-968; VASsY Zoltán: Schrödingerék macskája és más történetek. A kvantumfizika világképéről - józan ésszel. 5. fejezet. http://mek.oszk.hu/00500/00571/html/ (2018. 07. 29.). 
tet azóta nemcsak időben késleltetve, hanem térben eltérve is elvégezték, és 140, illetve $3500 \mathrm{~km}$ távolságból is ugyanaz lett az eredmény. ${ }^{69}$ Mivel a kísérletek során minden fizikai kölcsönhatást kizártak, ami a részecske viselkedését befolyásolhatta volna, Neumann János és Wigner Jenő szubjektív értelmezést kapcsolt a jelenséghez. ${ }^{70}$ Vagyis elképzelhetőnek tartották, hogy a részecske a tudat hatására kerül ki a szuperponált állapotból és viselkedik részecskeként.

Wigner azonban rámutatott egy paradoxonra (ezt nevezik Wigner barátja paradoxonnak): mi a helyzet akkor, ha két egymástól független szubjektív tudat van? Melyik tudat hatására omlik össze a hullámfüggvény? Sok évtizeddel a probléma felvetését követően több fizikus egymástól függetlenül ugyanazt a megoldást kínálta a fenti paradoxon feloldására: a tudat valójában egységes, nem helyhez kötött (non-local consciousness), kozmikus természetű valami, mely ott húzódik a két helyhez kötött személy valósága mögött. ${ }^{71} \mathrm{~A}$ két személy választása csak jelképes, hisz valójában mindkettejük esetében az egyedül létező tudat hozta meg a választást, elkerülve ezzel bármiféle ellentmondást. ${ }^{72}$

A nonlokalitást utóbb kísérleti úton is többször bizonyították. ${ }^{73} E$ kísérletek nemcsak a tudat nonlokalitása kapcsán, hanem akként is értelmezhetők, hogy az elemi részecskék világában megfigyelhető jelenségek olyan „makro” környezetben is müködnek, mint az emberi agyi folyamatok. ${ }^{74}$ Ezt a következtetést erősítette meg például az a kutatócsoport, amely egy több mint 450 atomból álló összetett szerves molekulát vizsgált. ${ }^{75}$ Visszatérve az elemi részecskék világába, 1935-ben Einstein, Podolsky és Rosen publikált egy tanulmányt, ${ }^{76}$ amelyben korrekt számításokkal levezették a szerzők vezetéknevének kezdőbetűje után EPR-paradoxonnak nevezett kvantumfizikai jelenséget. Ezt a jelenséget lehetetlennek tartották, ezért azt feltételezték, hogy valamilyen hiba van a kvantumfizika elméletében. $A$ „lehetetlennek

69 Vedovato, Francesco (et al): Extending Wheeler's delayed-choice experiment to space. Science Advances, 2017/3. http://advances.sciencemag.org/content/advances/3/10/e1701180.full.pdf (2018. 12. 10.).

70 VASsY: i. m., 9. fejezet.

71 László Ervin a nonlokális információáramlás mezőjét nevezi Akasha-mezőnek, amely mező mindent mindennel összeköt (LÁszLó: i. m., 82). Robert Lanza szerint is a kvantummechanika bizonyítja, hogy valamenynyien egy tér és idő által nem korlátozott nagyobb tudat részei vagyunk (LANZA, Robert: The wise science. The humanist, 1992/11-12, 24-26). Ugyanilyen holisztikus szemléletet képviselt már korábban is több más fizikus, például: CAPRA, Fritjof: The Tao of Physics. Shambhala, Boulder, 1975; ZukAv, Gary: The dancing Wu Li masters: An overview of the New Physics. Morrow, New York, 1979.

72 Goswami, Amit: Physics within non-dual consciousness. Philosophy East and West, 2001/4, 535-544.

73 Lásd például Grinberg-Zylberbraum, J.-Delaflor, M.-Attie, L.-Goswami, A.: The Einstein-Podolsky-Rosen Paradox in the Brain: The Transferred Potential. Physics Essays, 1994/4, 422-428; HÉJJAs István: Tudatosság és értelem az Univerzumban. https://vdocuments.mx/tudatossag-es-ertelem-az-univerzumban.html (2018. 08. 01.).

74 A kvantumtudatosság leginkább elterjedt elmélete: HAMEROFF, Stuart-PenRose, Roger: Consciousness in the universe: A review of the 'Orch OR' theory. Physics of Life Reviews, 2014/11, 39-78. A szerzők a sokak által kritizált „Orch OR” elméletüket a kritikák figyelembevételével továbbfejlesztették, és továbbra is úgy vélik, hogy a tudatosságnak fundamentális szerepe van az univerzum törvényeinek müködésében.

75 Gerlich, Stefan (et al): Quantum interference of large organic molecules. Nature Communications, 2011/2, 1-5. A külső megfigyelő egy antropikus elv formájában is megnyilvánul a kozmológiában. Lásd erről a 4.3. (Kozmológia) alpontot.

76 Einstein, Albert-Podolsky, Boris-Rosen, Nathan: Can Quantum-Mechanical Description of Physical Reality Be Considered Complete? Physical Review, 1935/10, 777-780. 
túnő" effektus lényege, hogy ha két elemi részecske, például két elektron kölcsönhatásba lép egymással, és azután szétválnak az útjaik, közöttük továbbra is fennmarad egyfajta "nem lokális” kapcsolat, és a „viselkedésük” szinkronban marad például úgy, hogy a két elektron spinje (pörgése) mindig egymással ellentétes irányú lesz. Úgy is fogalmazhatunk, hogy a két ikerrészecske sohasem válik függetlenné egymástól. ${ }^{77}$ Einstein azért tartotta lehetetlennek a jelenséget, mert az a „nem lokálisan csatolt" kvantumobjektumok között azonnali kölcsönhatást feltételez, és ez ellenkezik a relativitáselmélettel, amely kizárja, hogy a téridőn belül bármi gyorsabb legyen a fénysebességnél. A számítás helyességét 1982-ben Aspect és társai kísérleti úton is igazolták, tehát Einstein tévedett. ${ }^{78}$

Az Aspect-kísérletben két ellentétes irányban megfigyelt részecske (például egy elektron és pozitron) vagy két foton szerepel, melyeket a kibocsátás helyétől egyenlő távolságban detektálnak. A kísérletek célja az együtt kibocsátott fotonok polarizációs irányának meghatározása. Fotonok polarizációját vizsgálva Aspect és munkatársai azt találták, hogy a két polarizációs állapot, amit egyidejüleg detektáltak, éppen ellentétes. A koppenhágai iskola ebböl arra következtet, hogy a fotonok a kibocsátás után is állandó kapcsolatban maradnak, mintegy „összefonódva” (entanglement), így amikor az egyik foton felvesz egy polarizációs irányt, a másik ehhez késlekedés nélkül „,igazodik”. Az összefonódott elemi részecskék közötti információáramlás tehát minden jel szerint létezik, sőt éppen ennek ismeretében fejlesztik a kvantumszámítógépeket.

Mindez csak töredéke a fizika legújabb eredményeinek, és nem meglepö, hogy Max Planck, a kvantumfizika atyja már a 20. század elején azt javasolta, hogy a tudatot kell a valóság alapjává tenni. Szerinte ugyanis az anyag a tudatból származik és nem fordítva, ${ }^{79}$ mint ahogy azt még sokan feltételezik napjainkban is. De említhetjük még az ugyancsak Nobel-díjas Erwin Schrödingert, aki szintén úgy vélte, hogy a tudat a fundamentális tényező, nem az anyag. ${ }^{80} \mathrm{~A}$ kvantumfizika tehát, annak ellenére, hogy eredményeit bizonyos esetekben másként is lehet értelmezni, igazolni látszik, hogy a tudat elsődleges az anyaghoz képest, az anyag a tudattól nem független realitás és a nonlokalitás jelenségéböl következően a tudat bizonyos aspektusai meghaladják a téridő-kontinuumot.

\subsection{Tudatkutatás ${ }^{81}$}

Ismert mondás, hogy amikor tudatról beszélünk, mindenki sejti, miröl van szó, de amikor meg kell határozni, akkor még a legnagyobb gondolkodók is elnémulnak. ${ }^{82}$

77 Geszti Tamás: Kvantumtechnika. Typotex, Budapest, 2007, 224.

78 Aspect, Alain-Grangier, Philippe-Roger, Gérard: Experimental realization of Einstein-Podolsky-RosenBohm Gedankenexperiment: a new violation of Bell's inequalities. Physical Review Letters, 1982/2, 91-94.

79 Sullivan, J. W. N.: Interviews With Great Scientists VI. - Max Planck. The Observer, 25 January $1931,17$.

80 MoORE, Walter: A Life of Erwin Schrödinger. Cambridge University Press, Cambridge, 1994, 181.

81 Simon-Székely Attila szerint a 20. század végén új tudományág született, a tudat tudománya, amely egyfajta multidiszciplináris jelleget ölt. Ebben a szakmaközi dialógusban képviselteti magát többek között az elmefilozófia, a pszichológia, a kognitív tudományok általában, a humán genetika, a kísérleti neurológia. Simon-Székely Attila: A tudat-biopszichológia alapvonalai. Appendix, Marosvásárhely, 2005, 15.

82 VÁRKONYı Hildebrand: A tudat fogalmáról. Összetartás Nyomda, Győr, 1912, 35-36. 
Ennek ellenére rengeteg meghatározás létezik, amelyek attól függően változnak, hogy éppen milyen tudományterületről van szó. ${ }^{83}$ Jelen tanulmányban e fogalmat abban az értelemben használom, hogy a tudat téridőn kívüli természetü. Ez a kvantummechanikában az a szint, ahol az EPR-jelenség megfigyelhető. ${ }^{84}$ Többek között Manousakishoz, Pradhanhoz és Schwartzhoz ${ }^{85}$ hasonlóan úgy vélem, hogy az egyéni tudat része egy nagyobb, ugyancsak transzcendens univerzális Tudatnak. ${ }^{86}$ Ugyanakkor hangsúlyozni kell, hogy az univerzális Tudat nem az egyéni tudatok öszszessége, mint ahogy - rendszerelméleti hasonlattal élve - a rendszer sem egyenlö az egyes elemek összességével, hanem az alrendszerektől eltérő, saját tulajdonságokkal írható le.

Nézzük most meg, hogy miként viszonyul egy effajta meghatározáshoz a tudattudomány. Mindenekelött érdemes felidézni, hogy „a tudatos agy, az öntudat a tudomány legnagyobb megoldatlan problémája". ${ }^{87}$ Tudjuk, hogy vagyunk, mindenkinek megvan az egyéni és nagyon bensőséges tapasztalata a létezésröl, ugyanakkor ez egzakt tudományos módszerekkel nem igazolható. Legalábbis eddig ez volt a fő megközelítés. A 20. század közepétől azonban a tudatkutatás keretében „olyan kérdésekre is tudományos igényü választ szeretnének nyújtani, mint hogy mi a kapcsolat az agy és a tudat között, hogy van-e lélek, hogy milyen biológiai magyarázata van az "Én « tudatának, vajon az agy csak bio-gép-e". ${ }^{88}$ Vagyis a tudatkutatás már túllépett az elme filozófiáján, és interdiszciplináris-empirikus úton akarja megérteni a tudatot. ${ }^{89}$ Vannak, akik a különböző diszciplínák eltérő fogalomhasználatából adódó bizonytalanságokra hivatkozva módszertani szempontból kritizálják ezen új tudományterület tudományközi jellegét. ${ }^{90} \mathrm{Ez}$ a kritika jelen tanulmányra is igaz lehet, hiszen az úgy állítja párhuzamba az egyes szaktudományokat, hogy nem egységesíti a fogalomhasználatot. Csakhogy e tanulmány nem hozzátenni akar a tudatkutatás eredményeihez, hanem összefoglalásukkal megkísérli a jogtudományba integrálni azokat. Jelen írástól nem várható el, hogy olyan hiányosságokat pótoljon, amiket még ezen új tudományterületen sem rendeztek maradéktalanul.

Jelenleg ezt az új és intenzíven fejlődő komplex tudományterületet még döntöen az a materialista hipotézis uralja, ${ }^{91}$ miszerint a tudatjelenségek a neuronok és a

83 PereirA, Alfredo-Ricke, Hans: What is consciousness? Towards a preliminary definition. Journal of Consciousness Studies, 2009/5, 28-45.

84 Pradhan, Rajat K.: Subject-Object Duality and States of Consciousness: A Quantum Mechanical Approach. Neuro Quantology, 2010/3, 264.

85 Schwartz, Stephan: Kuhn, consciousness, and paradigms. Explore: The journal of science and healing, 2018/4, 261.

86 KoRoknAl-SZÉnYEI: i. m., 3.

87 HéJJAS István: Öshagyomány, misztikum és tudomány. In: Simon-Székely Attila (szerk.): Lélekenciklopédia 2. Gondolat, Budapest, 2016, 470. A tudatkutatásról átfogóan ír HoRváTH Lajos: A tudat metamorfózisa: Az interdiszciplináris tudatkutatás tudományfilozófiai-hermeneutikai elemzése. Debreceni Egyetemi Kiadó, Debrecen, 2013.

88 VIzI E. Szilveszter-AltRICHTER Ferenc-NYírI Kristóf-PléH Csaba: Agy és tudat. BIP, Budapest, 2002, 9.

89 Boros János: Neurotudományok és tudat. Informatika, fiziológia, filozófia. Korunk, 2013/5, 21-29; Buzsákı György: Agy-tudat: válaszok egy nehéz problémára. Magyar Tudomány, 2001/10, 1176-1181.

90 HORVÁTH Lajos: i. m.

91 Facco, Enrico-Lucangel, Daniela-Tressold, Patrizio: On the science of consciousness: epistemological reflections and clinical implications. Explore, 2017/5-6, 168. 
neurális hálózatok mechanizmusaira vezethetők vissza. ${ }^{92}$ Ugyanakkor hiányoznak a közvetlen bizonyítékok arra vonatkozóan, hogy a neuronok vagy neurális hálózatok hogyan produkálják az elme és a gondolatok szubjektív esszenciáját, a szubjektív tapasztalatot („,nehéz probléma”). ${ }^{93}$ Ez képezi az idegtudomány egyik legnagyobb kihívását. ${ }^{4}$ Ezzel párhuzamosan azonban léteznek olyan jelenségek (például a testen kívüli, halálközeli élmények, érzékszerveken kívüli észlelés), amelyeket az agykutatás eredményei a mai napig nem tudtak megmagyarázni a hagyományos materialista megközelítés keretében. ${ }^{95}$ Az idegtudomány máig megválaszolatlan kérdései (például a „nehéz probléma”) és az előbb említett jelenségek hatására az utóbbi években egyre gyakrabban lehet találkozni olyan munkákkal, amelyek a tudat immateriális, transzcendens jellegét és fundamentalitását állítják. ${ }^{96}$ Itt természetesen

92 HoRváth Lajos: i. m., 18, 150; FACCo-LuCANGELI-Tressoldi: i. m., 168.

93 A „nehéz probléma” kifejezést David Chalmers nevéhez szokták kötni (lásd CHALmers, David J.: A tudatos tapasztalat rejtélye. Kellék, 2005/27-28, 8). „A [nehéz] probléma megoldásától azonban majdnem végtelen távolságra vagyunk még, és a jelenleg konceptuálisan belátható, illetve respektálható megoldási lehetőségek is igencsak korlátozottnak tünnek" - írja Altrichter Ferenc filozófus, aki összességében mégis bízik a probléma megoldhatóságában. Lásd ALTRICHTER Ferenc: A tudat két aspektusa: intencionalitás és qualia. Magyar Tudomány, 2001/10, 1207-1213.

94 HORVÁTH Lajos: i. m., 150.

95 HoRvÁth Lajos: i. m., 162.

96 Lásd csupán az alábbi tanulmányokat: ECcLEs, John-Popper, Karl: The Self and Its Brain: An Argument for Interactionism. Routledge, London, 1977; Eccles, John C.: How the Self Controls its Brain. Springer, Berlin, 1994; Devenish, Philip: Mind, Brain, and Dualism. The Journal of Religion, 1981/4, 422-427; ChALMERS, David: Facing Up to the Problem of Consciousness. Journal of Consciousness Studies, 1995/2, 200-219; CARDENA, Etzel: Toward comprehensive neurophenomenological research in hypnosis and meditation. In: Raz, Amir-Lifshitz, Michael (eds.): Hypnosis and Meditation. Towards an Integrative Science of Conscious Planes. Oxford University Press, New York, 2016, 281-300; VARELA, Fransisco: Neurophenomenology: a methodological remedy to the hard problem. Journal of Consciousness Studies, 1996/4, 330-350; BRABANT, Olivier: More Than Meets the Eye: Toward a Post-Materialist Model of Consciousness. Explore, 2016/9-10, 347-354; MoRRIS, Robert: Research methods in experimental parapsychology. European Journal of Parapsychology, 2001/168, 8-18; MACHLEIDT, Wielant-SieBERER, Marcel: From Kraepelin to a modern and integrative scientific discipline: the development of transcultural psychiatry in Germany. Transcultural Psychiatry, 2013/6, 817-840; DeIN, Simon-BHul, Kamaldeep Singh: At the crossroads of anthropology and epidemiology: current research in cultural psychiatry in the UK. Transcultural Psychiatry, 2013/6, 769-791; NodA, Fumitaka: Reflections on the road to becoming a cultural psychiatrist. Transcultural Psychiatry, 2011/1-2, 79-89; Bravo, Gary-Grob, Charles: Shamans, sacraments, and psychiatrists. Journal of Psychoactive Drugs, 1989/21, 123-128; FRECSKA Ede-LunA, Luis Eduardo: Neuro-ontological interpretation of spiritual experiences. Neuropsychopharmacologia Hungarica, 2006/8, 143-153; Kelly, F. EdwardWilliams Kelly, Emily-Crabtree, Adam-Gauld, Alan-Grosso, Michael-Greyson, Bruce: Irreducible mind. Toward a psychology for the 21st century. Rowman \& Littlefield, Lanham, 2007; NePpE, Vernon-CLOSE, Edward: EPIC Consciousness: A Pertinent New Unification of an Important Concept. Journal of Psychology \& Clinical Psychiatry, 2014/6, https://medcraveonline.com/JPCPY/JPCPY-01-00036.pdf (2018. 08. 14.); Schwartz, Jeffrey-Begley, Sharon: The Mind \& The Brain: Neuroplasticity and the Power of Mental Force. Happer Perennial, New York, 2002, 9; PARniA, Sam-Fenwick, Peter: Near Death Experiences in Cardiac Arrest: Visions of a Dying Brain or Visions of a New Science of Consciousness. Resuscitation, 2002/1, 5-11; Vızı E. Szilveszter: A tudás hídjai. Kossuth, Budapest, 2005. Elisabeth Blackburn, aki 2009-ben orvosélettani Nobel-díjat kapott a telomeráz enzim felfedezéséért, több kutatóval együtt bizonyítékot talált arra, hogy a módosult tudatállapotok a gének szintjén képesek változásokat létrehozni az emberi sejtekben: Epel, E.-Daubenmier, J.-Moskowitz, J. T.-Folkman, S.-Blackburn, E.: Can meditation slow rate of cellular aging? Cognitive stress, mindfulness, and telomeres. Annals of the New York Academy of Sciences, 2009/8, 
nem arról van szó, hogy ezek a szerzők a tudáshiányt próbálják áthidalni a transzcendenciába vetett hittel. Mint látni fogjuk, arról van szó, hogy az új megközelítést olyan empirikus kutatások eredményei igénylik, amelyek a hagyományos világnézet keretei között egyszerüen nem értelmezhetőek.

Joggal merülhet fel a kérdés, hogy e kísérleti eredmények miért nem terjedtek el szélesebb körben. Kutatások szerint ennek oka, hogy az emberek, így a tudományos közösség tagjai is, ösztönösen nyitottabbak azokra az információkra, amelyek azoktól érkeznek, akiknek a világnézetét osztják. Ezzel párhuzamosan azokkal az információkkal, amelyek olyanoktól származnak, akiknek a világnézetével nem azonosulnak, elutasítóak. ${ }^{97}$ Vagyis inkább követnek egy számukra biztonságot nyújtó nagyobb közösséget és a csoportkonszenzust, mint a tényeket. ${ }^{98}$ Holott neurobiológiai, ${ }^{99}$ neuroteológiai, ${ }^{100}$ nemlokális tudatossággal kapcsolatos kísérletek, ${ }^{101}$ az érzékszerveken kívüli érzékeléssel, ${ }^{102}$ valamint a halálközeli és testen kívüli élményekkel kapcsolatos kutatások ${ }^{103}$ eredményei azt a paradigmát támasztják alá, amely a tudatnak az anyaghoz viszonyított elsődlegességét, a tudat bizonyos aspektusainak téridőn kívüli természetét, valamint azt mondja ki, hogy valamennyi tudat (azok fizikai megnyilvánulásától függetlenül) része egy univerzális Tudatnak, azzal kölcsönös kapcsolatban áll. ${ }^{104}$

Az érzékszerveken kívüli érzékelés (extra-sensory perception, ESP) jelenség kutatása például több évtizedes múltra tekint vissza. Többek között a Leonid Vasiliev orosz kutató által vezetett kutatócsoport már az 1950-es évektől kezdve olyan

34-53. Legutóbb 2017-ben jelent meg Imants Barušs és Julia Mossbridge könyve Transcendent Mind címmel. Az egyébként konzervatívnak számító American Psychological Association gondozásában megjelent könyv szerzői azt állítják, hogy a tudat téren és időn kívül létező fundamentális tényező, és az individuális tudatok egy univerzális Tudat részeiként egymással is kapcsolatban állnak. Álításaikat a kvantumfizikára, a nemlokális kísérleti tudatkutatásokra, neurofenomenológiára, illetve a klasszikus és kortárs filozófusokra támaszkodva fogalmazzák meg: BARUšs, Imants-MossBriDge, Julia: Transcendent Mind: Rethinking the Science of Consciousness. American Psychological Association, Washington DC, 2016.

97 De Witt, Annick-de Boer, Joop-Hedlund, Nicholas-OsseweiJer, Patricia: A new tool to map the major worldviews in the Netherlands and USA, and explore how they relate to climate change. Environmental Science\&Policy, 2016/11, 101.

98 Kahan, Dan-Braman, Donald-Jenkins-Smith, Hank: Cultural cognition of scientific consensus. Journal of Risk Research, 2011/2, 147-174.

99 FreCSKa-LunA: i. m, 143-153.

100 Albright, Carol Rausch: Neurotheology. In: Eisen, Arry-Laderman, Gary (eds.): Science, Religion, and Society: An Encyclopedia of History, Culture, and Controversy. M.E. Sharpe, Armonk, New York, 2007, 536-542.

101 A nem lokális jelző arra utal, hogy a tudat nem a szervezet neuroanatómiájának része. ScHWARTz, Stephan A.: Six protocols, neuroscience, and near death: an emerging paradigm incorporating nonlocal consciousness. Explore, 2015/4, 258.

$102 \mathrm{Az}$ érzékszerveken kívüli érzékelés (extra-sensory perception, ESP) több jelenséget foglal magában: a telepátiát (tudomásszerzés valamilyen emberi tudattartalomról), a clairvoyance-t (tudomásszerzés egy tárgy objektív tulajdonságáról; a szónak egyelőre nincs általánosan elfogadott magyar megfelelője) és a prekogníciót (tudomásszerzés jövőbeli eseményröl).

103 Schwartz (2015): i. m.; Facco-Lucangeli-Tressoldi: i. m.; Barušs-Mossbridge: i. m.; Horváth: i. m., 133-145; PaulinY Tamás: Parapszichológia. In: Simon-Székely Attila (szerk.): Lélekenciklopédia 2. Gondolat, Budapest, 2016, 479-519.

104 SchWARTz (2018): i. m., 261. 
kísérleteket végzett, amelyek eredménye arra enged következtetni, hogy a telepátia nemcsak hogy létező jelenség, de nem is egyszerüen emberi agyak között történik. A kísérlet során ugyanis úgy végeztek gondolatátvitelt - még 1700 km-es távolságból is -, hogy a kísérleti alanyokat (mind fogadó, mind adó oldalról) Faradaykalitkába, acélkamrába vagy ólomkamrába helyezték. A telepátia ennek ellenére is müködött. Ez arra enged következtetni, hogy a telepatikus információátvitel nem az agy által kibocsátott elektromágneses hullámokkal történik, az agyhullámok ugyanis az említett árnyékolásokon nem lennének képesek áthatolni. Vasiliev kutatásai tehát azt a feltevést erősítik, hogy az emberi tudat transzcendens jellegű. A mai napig számos további kísérlet igazolja természettudományos alapon az ESP-jelenségek létét és valódiságát. Vassy Zoltán szerint - aki magát egyébként kifejezetten materialista parapszichológusnak tartja, így igen szkeptikus - időnként felmerülnek ugyan kétségek egyes ESP-kísérletek módszertanát tekintve, összességében azonban a kísérletek eredményei statisztikai szempontból kizárják annak lehetőségét, hogy érzékszerveken kívüli információátvitel csupán véletlenül történjen. Vagyis az ESP tudományosan bizonyított, létező jelenség. Vassy egy brit pszichológust idéz: „Hacsak nincs valami gigantikus mértékü összeesküvés mintegy harminc egyetemi tanszék és többszáz, különféle tudományos hátterü kutató között - akik közül nem egy eredetileg ellenségesen viszonyult a parapszichológiához -, a pártatlan szemlélö egyetlen következtetést vonhat le: azt, hogy léteznek emberek, akik képesek tudomást szerezni mások gondolatairól vagy a világban máshol történő eseményekröl a tudomány előtt egyelöre ismeretlen módon." ${ }^{05}$ A fent hivatkozott kísérleti eredmények, különösen a nemlokális tudatossággal kapcsolatosak, egy az egymilliárdhoz hibalehetőséggel rendelkeznek a rendkívül szigorú kutatási protokolloknak köszönhetően. Csak összehasonlításképpen: amikor a CERN munkatársai 2012-ben megtalálták a Higgs-bozont, egy a háromszázmillióhoz volt az esélye annak, hogy valóban a nevezett elemi részecskét azonosították. Ez a hibalehetőség elég volt ahhoz, hogy mintegy 6000 fizikus támogassa azt a következtetést, hogy a Higgs-bozon létezik. A tények tehát magukért beszélnek, és csak idő kérdése, hogy ezt szélesebb körben mikor fogadják el. ${ }^{106}$

A tudatkutatással kapcsolatos eredményeket szinte lehetetlen ilyen szűkre szabott keretek között felvázolni. Mindenesetre legalább egy igen befolyásos tudós nevét még meg kell említenem. Az eredetileg őssejt-specialista Robert Lanza „biocentrizmus” néven egy új hipotézist állított fel, miszerint a létezés középpontjában az élet áll, és egy kozmikus tudatosság (cosmos-consciousness) hozza létre az univerzumot, nem pedig fordítva, mint ahogy azt eddig feltételezték. Lanza az elméletét a természettudományok, például az általam is említett kvantumfizika, illetve a modern biológia eredményeire alapozza. ${ }^{107}$

105 Eysenck, Hans: Sense and Nonsense in Psychology. Penguin Books, Baltimore, MD, 1966, 131-132. Idézi VASSY: i. m., 5. fejezet.

106 Goswami kvantumfizikus szerint, ha integrálni akarjuk a tudomány és a spiritualitás világát, szakítanunk kell azzal a paradigmával, ami a tudat helyett az anyagot fogadja el a valóság alapjának. GoswAmı, Amit: The Self-aware Universe: How consciousness Creates the Material World? Putnam's Sons, New York, 1993, 1-2.

107 Lanza, Robert-Berman, Bob: Biocentrism: How Life and Consciousness are the Keys to Understanding the True Nature of the Universe. BenBella Books, Dallas, Texas, 2009; LanzA, Robert-Berman, Bob: Beyond 
Összefoglalva tehát azt láthatjuk, hogy a tudatkutatásban még mindig a materialista gondolkodási keret az uralkodó. Ennek ellenére a tudat és ezzel a lélek fundamentális jellegét, illetve téridőn kívüli természetét és az egyéni tudatok összekapcsoltságát egyre több olyan tény támasztja alá, amelyeket már sokáig nem érdemes semmibe venni. De ha netán ezen eredmények figyelmen kívül is maradnak még egy ideig, létüknél fogva akkor is joggal képezhetik alapját olyan, az enyémhez hasonló kutatásoknak, amelyek a környezeti, társadalmi problémák megoldására szolgálnak.

\subsection{Kozmológia}

„A kozmológia az észlelhető világegyetem nagyléptékü szerkezetét és dinamikáját, kialakulását és fejlődését elméleti modellekkel leíró, magyarázó [...] tudomány." 108 A kozmológia tudományán belül a téma szempontjából az univerzum „finomhangoltságát” kell kiemelnem. Eszerint a természet egyes alapállandói (például bizonyos elemi részecskék tömege, az alapvető kölcsönhatások relatív erőssége stb.) olyan értékekkel rendelkeznek, amelyek, ha kicsit is eltérnének ettöl, akkor az a földi élettel összeegyeztethetetlen lenne.

Ennek a jelenségnek a magyarázatára jelentek meg az ún. antropikus elvek, amelyekböl hármat említek. A gyenge elv (weak anthropic principle, WAP) azt mondja ki, hogy „helyzetünk az univerzumban szükségképpen annyira kiváltságos, amilyen mértékben összeegyeztethető létünkkel, mint tudatos megfigyelökével". ${ }^{109}$ A WAP szemben áll azzal a már hagyományosnak számító kopernikuszi elvvel, miszerint az ember nem foglal el kiváltságos helyet az univerzumban, sőt teljesen jelentéktelen. Carter, az elv megfogalmazója előterjesztette az erős antropikus elvet (strong anthropic principle, SAP) is, miszerint az univerzumnak olyan tulajdonságokkal kell rendelkeznie, amelyek lehetővé teszik benne az élet kifejlödését, történetének valamilyen lépcsőfokában. A kvantumtechnika szubjektív koppenhágai értelmezése nyomán a finomhangoltság jelenségét úgy is magyarázzák, minthogy „megfigyelök szükségesek ahhoz, hogy létrehozzák az univerzumot" (participatory anthropic principle, PAP). ${ }^{110}$

Mint látható, univerzumunk finomhangolt jellege megkérdőjelezi azt az alapállítást, miszerint a tudat az anyagból jött létre, csupán egy abszurd véletlen eredményeként. Az antropikus elvek elterjedésének egyik velejárója tehát, hogy az élet, a megfigyelök és ezáltal a tudat bekerült a kozmológiai érvelések középpontjába, és

Biocentrism. Rethinking Time, Space, Consciousness, and the Illusion of Death. BenBella Books, Dallas, Texas, 2016.

108 GrandPIERRE Attila: Kozmológia és antropikus elvek. In: Simon-Székely Attila (szerk.): Lélekenciklopédia 2. Gondolat, Budapest, 2016, 415.

109 CARTER, Brandon: Large number of coincidences and the anthropic principle in cosmology. In: Longair, M. (ed.): Confrontation of cosmological theories with observational data. Reidel, Dordrecht, 1974, 291. Idézi HETESI Zsolt: Az univerzum modelljei és az emberi lét. In: Simon-Székely Attila (szerk.): Lélekenciklopédia 2. Gondolat, Budapest, 2016, 412.

110 Hetesl: i. m., 413. 
ezeknek az univerzum kialakulásában kulcsszerepet tulajdonítanak. ${ }^{111} \mathrm{Az}$ antropikus elvek jelentőségét tovább erősíti, hogy a WAP-ot időközben több tudományos eredmény is visszaigazolta. Például a kozmológiai állandó értékére a WAP segítségével következtettek helyesen. ${ }^{112}$

\subsection{A modern tudomány és a transzcendens tudat viszonya - értékelés}

Mint láthattuk, a kvantumfizika, az interdiszciplináris tudatkutatás és a kozmológia legújabb elméletei és eredményei - hasonlóan a puzzle egyes darabjaihoz -, ha önmagukban nem is, de egymáshoz illesztve olyan nagyobb képet alkotnak, amely véleményem szerint megkérdőjelezi a materializmus helytállóságát, és alátámasztja az ember eredeti természetének transzcendens jellegét. Ezt a véleményt nem utolsósorban különböző tudományterületek igen tekintélyes képviselői is osztják.

Elképzelhető ugyanakkor, hogy bizonyos jelenségeket másként is lehet értelmezni, ezért nem feltétlenül jelentenek minden tekintetben kétséget kizáró bizonyítékot - különösen ha valaki teljesen szkeptikus talajon áll. Továbbá az egyes tudományterületek elméleteiben elképzelhetők olyan hibák is, amelyeket most még nem látni. Maga Einstein is, amikor megkérdőjelezte az összefonódás jelenségét, arra a következtetésre jutott, hogy a kvantumfizika elméletében van valami hiba - igaz, félelme utóbb mégis alaptalannak bizonyult. Ha azonban a fenti eredményekhez hozzátesszük, hogy lényegében valamennyi vallás alapvető mondanivalója, hogy örök létezőként egy örök világhoz tartozunk, és ezt nagyon sok szent ember személyes példájával is igazolta (többek között Jézus Krisztus, Mózes, Mohamed, Assisi Szent Ferenc, Buddha, Srí Caitanya, Pio atya), az véleményem szerint sokkal több, mint merő véletlen, és megerősíti a bemutatott kutatási eredmények hitelességét. ${ }^{113}$

Akárhogyan is, a fentiekben vázolt és a tudományos életben talán szokatlan irány arra legalábbis mindenképpen jogosít, hogy a környezeti, társadalmi problémákat abból a kiindulópontból is vizsgáljuk, hogy lényünk túlmutat a téridő korlátain. A társadalmi, környezeti elidegenedés pedig csak tükörképe az önmagunk lényegétöl való elszigetelődésnek. Ez tehát lehet egy olyan munkahipotézis, amelyre jogtudományi keretek között is építkezni lehet. Különösen ha belegondolunk, hogy valójában a materializmus világnézete finoman szólva sem kétségek nélküli, mégis döntően arra építkezik minden tudományos megközelítés és gazdasági, társadalmi szabályozás. A magam részéről ezért megindokoltnak tartom, hogy miért támaszkodom a Stephan Schwartz által új metaparadigmaként jelölt alapokra.

111 McGıNn, Colin: Öntudat és kozmológia: terjesztem a hiperdualizmust. Magyar Filozófiai Szemle, 2002/1-2, 175-207.

112 GrandPIERRE: i. m., 421-422.

113 Simon-SzÉKely (2008): i. m., 7; Hankiss (2018): i. m., 1581. 


\section{Az „Örök rend”}

Mit is jelent a fenti bekezdésben megfogalmazott következtetés jogi nézőpontból? Azt, hogy létezhet a valóságnak egy olyan dimenziója is, amit eddig figyelmen kívül hagytunk, és a mai jogrendszereink ezt szentesítették. A modern jog és a modern társadalmak e jelek szerint nincsenek összhangban a valósággal és az azt megtestesítő örök természeti törvényekkel. Ha ez így van, a helyzet pusztító és egészségtelen is. Ennek alátámasztására a legföbb indikátor nem más, mint az ökológiai korlátok átlépése. Ahogy a tanulmány elején írtam, az ökológiai korlátok áthágása és e tilosban járás fenntarthatatlansága természettudományos alapon bizonyított tény. Ez a szomorú helyzet feketén-fehéren mutatja, hogy valami nincsen rendben. Szó szerint: nincs rend. Hiába áltatjuk magunkat a technológiai fejlődésbe vetett hittel. Aki holisztikus módon közelíti a környezeti problémákat, az jól láthatja, hogy a megoldásukra kifejlesztett legtöbb technológiai eredmény olyan, mint az a gyógyszer, aminek több a mellékhatása, mint a haszna. ${ }^{114} \mathrm{Ha}$ vissza akarjuk állítani a rendet, a harmóniát a természeti környezetben és a társadalomban egyaránt, akkor minden jogrendszernek vissza kellene térnie az örök természeti törvényekhez.

Ez a gondolat emlékeztet a Platón, Arisztotelész és Aquinói Szent Tamás által képviselt klasszikus természetjogi felfogáshoz, amely szintén megkülönböztetett emberi és örök törvényeket, ahol az elöbbinek igazodnia kell az utóbbihoz. Az univerzális rend (rta) és az ahhoz való igazodást segítő törvények léte ugyanakkor a klasszikus hindu jogi kultúrában is teljesen természetes. Tehát azt mondhatjuk, hogy az emberi és az örök törvény megkülönböztetésének a jogban komoly hagyománya van.

Ha ezt a gondolatot elfogadjuk, két kérdés marad. Egyrészt, melyek azok az örök törvények, amelyeket az ember alkotta jognak követnie kellene, másrészt mi a következménye annak, ha mégsem követi?

Aquinói Szent Tamás örök törvény (lex aeterna) alatt az isteni bölcsesség eszméjét értette, amely minden tevékenység és változás irányítója. ${ }^{115} \mathrm{Ez}$ lényegében az egész univerzumot szabályozó elv, amely Susan Dimock szerint magában foglalja mindazokat a tudomány által is feltárt (fizikai, kémiai, biológiai, pszichológiai stb.) törvényszerüségeket, amelyek az egész univerzumot irányítják. ${ }^{116}$ Szent Tamás szerint az ember hit által jut el az örök törvény parancsainak felismeréséhez. ${ }^{117} \mathrm{~A}$ tradicionális hindu jogban az rta igazságot, természetes rendet jelenti, amely a kozmosz valódi és örök mozgására utal. A rta a srutikból (Védák, isteni kinyilatkoztatások) és smrtikből (szent hagyomány) ismerhető meg.

A modern (környezetjogi) szakirodalomban három állásponttal is találkoztam a fenti kérdéssel kapcsolatban. Cormac Cullinan az örök törvények kapcsán nem fogalmaz pontosan. Szerinte azok olyan tudományosan igazolható univerzális igazsá-

\footnotetext{
114 Huesemann- Huesemann: i. m.

115 Aquinó Szent Tamás: A Summa Theologiae kérdései a jogról. Szent István Társulat, Budapest, $2011,21$.

116 HıмmA, Kenneth Einar: Natural Law. In: Fieser, James-Dowden, Bradley (eds.): Internet Encyclopedia of Philisophy. https://www.iep.utm.edu/ (2018. 05. 21.).

117 Aquinóı Szent Tamás: i. m., 22.
} 
gok, mint például a gravitáció jelensége. ${ }^{118}$ Peter Burdon már több részlettel szolgál. Véleménye szerint azokat a természeti törvényszerüségeket, amelyeket az ember alkotta jognak követnie kell (Great Jurisprudence), az ökológia tudományából ismerhetjük meg. Egyrészt azért, mert valamilyen módon kézzelfoghatóvá kell tenni a követendő természeti törvényszerüségeket, másrészt mert a környezetvédelmi jog is nagyban támaszkodik az ökológia tudományára, harmadrészt mert az ökológia rámutat minden élölény szerves összekapcsoltságára, így képes kezelni az ember és természet elszigetelődéséből eredő problémát. ${ }^{119} \mathrm{~A}$ legrészletesebb válasszal Jan Laitos rendelkezik. Könyvében a szimmetriát tekinti olyan univerzális követelménynek, amely mindent átható és amihez mindennek igazodnia kellene. A szimmetria az ő értelmezésében azt jelenti, hogy „változás, változás nélkül”, ami további három elvet foglal magában: a megőrzés/megmaradás (conservation), az ekvivalencia (equivalence) és az egység (unification) törvényét. ${ }^{120}$

Mint látható, az örök törvények tartalmával kapcsolatban a modern álláspontok a természettudományokra, míg Aquinói Szent Tamás, illetve a tradicionális hindu jog a hitre, illetve isteni kinyilatkoztatásokra támaszkodnak. Véleményem szerint bármelyik úton (tapasztalat vagy isteni kinyilatkoztatásba vetett hit által) jutunk az örök törvények felismeréséhez, a két útnak ugyanoda kell vezetnie, lévén örök és egyetemes természeti törvényszerüségekröl van szó. Véleményem szerint ennek a feltételnek az előbb bemutatott, a kozmikus igazságokkal kapcsolatos modern álláspontok csak részben felelnek meg, mert a környezeti problémák okát etikai szinten, immanens módon ragadják meg és ott is próbálják kezelni, ami nincs teljesen összhangban a szentírásokkal.

Az általam képviselt rend, amit alább összegzek, a tanulmányban bemutatott kvantumfizikai, kozmológiai, tudatkutatási eredményekből körvonalazódik, és teljesen összhangban van a Bhagavad-gítával, így a rta egyik megnyilvánulásaként is értelmezhető. Ami a Bibliát illeti, ha nem is szó szerint, de álláspontom szerint abból is kiolvasható ilyen valóság. Mivel e rend mind a természettudományos eredményekkel, mind pedig a szent írásokkal összhangban áll, megfelel annak a feltételnek, amit az egyetemes és örök törvények kapcsán elvárunk. Álláspontom szerint tehát az alábbi négy lételméleti igazságot magában foglaló „Örök rendet” kellene érvényesíteni.

Az első legalapvetöbb törvény, hogy az ember és valamennyi élölény ${ }^{121}$ tudata transzcendens természetü (atman, pneuma, lélek). ${ }^{122}$

A másik fundamentális törvény arra épül, hogy az individuális tudatok, függetlenül a megnyilvánulási formájuktól, részei egy mindent átható, univerzális, transzcendens „Tudatnak” (Paramatma, Pneuma, Szentlélek), így azok egymással is össze vannak kapcsolódva. ${ }^{123} \mathrm{Az}$ egyéni és univerzális „Tudat” között kölcsönös informá-

118 Cullinan (2011): i. m.

119 Burdon, Peter: The Great Jurisprudence. In: Burdon, Peter (ed.): Exploring Wild Law: The Philosophy of Earth Jurisprudence. Wakefield Press, Kent Town, 2011, 66-67.

120 BÁnYAl (2017): i. m.

121 Lásd az 56. lábjegyzetet.

122 Biblia 1Thesz 5:23; BG 2.30.

123 BG 13.17 és 13.28. 
cióáramlás van. Az univerzális „Tudat” több, mint az egyéni tudatok összessége. A Paramatma/Szentlélek mind a Bhagavad-gíta, mind a Biblia szerint Istennek (csupán) az egyik aspektusa.

A harmadik alapvető igazság az első két fundamentális valóság kapcsolatára vonatkozik. Eszerint az egyéni tudat helyzeténél fogva alá van rendelve a mindent átható, univerzális „Tudatnak”.

A negyedik igazság, hogy az anyag ${ }^{124}$ természeténél fogva alá van rendelve a mindent átható, univerzális "Tudatnak”. ${ }^{125}$

Ami az örök törvényekkel ütköző emberi törvények érvényességét illeti, Aquinói Szent Tamás szerint minden törvény az örök törvényböl ered. Így, ha az emberi törvény eltér tőle, az már nem törvény. ${ }^{126}$ Ehhez hasonló következtetésre jut Burdon a modern szakirodalomban: ha a pozitív jog nincs összhangban az univerzális törvényekkel, akkor az egyszerüen érvénytelen, nem kell követni. Wood - bár az Amerikai Egyesült Államokról ír, de következtetése általánosítható - azt várja el, hogy az igazságszolgáltatásban lehessen érvényt szerezni a természeti igazságoknak. A bíráknak kellene megjeleníteniük a közjót és képviselniük e magasabb rendű törvényeket a környezet megóvása érdekében. ${ }^{127}$ Ezen természeti törvényszerüségek előtt véleménye szerint még az alkotmánynak is meg kell hajolnia.

Az örök törvényekbe ütköző emberi törvények érvénytelensége elméleti szempontból vitathatatlan. Ám ez - bár időnként előfordulnak pozití példák ${ }^{128}$ - a jelenlegihez hasonló társadalmi körülmények között a gyakorlatban rövid távon véleményem szerint érvényesíthetetlen. Ez független az örök törvények tartalmától, és azzal magyarázható, hogy őrültként viselkedő társadalmunkban a racionalitásnak nem sok esélye van. Ezt jól tudják a szabályozók is: nem lehet észérvekre támaszkodni, az érzelmi alapú reakciók sokkal erősebbek, még az értelmiségi rétegben is. ${ }^{129}$ Egyedül azt tartom elképzelhetőnek, hogy a tudomány fejlődésével, a természetes, illetve társadalmi környezetben bekövetkező változások elmélyülésével hosszabb távon felismerjük e törvények követésének valódi súlyát, és alkalmazkodni kezdünk hozzájuk. Hosszú távon tehát van remény.

Szeretném kiemelni, hogy a jognak nem egyszerüen azért kellene tiszteletben tartania az örök természeti törvényeket, hogy kínszenvedések közepette fenntartható módon élhessünk, hanem azért, hogy ezzel keretet nyújtson az önismeret elmélyítésének, és ezzel valóban elégedetté válhassanak, kiteljesedhessenek az emberek.

124 Lásd a 63. lábjegyzetet.

125 BG 13.15 és 13.30.

126 Aquinó Szent Tamás: i. m., 40.

127 Az új-zélandi Whanganui folyó jogalanyiságát kimondó jogszabály elfogadásakor például kifejezetten érv volt a maurik spirituális kapcsolata a folyóval. Az indiai legfelső bíróság is hasonló okok miatt nyilvánította jogi és élő személlyé a Gangeszt és a Jamunát. Bővebben lásd SzILÁGYı János Ede: A víz jogalanyisága újzélandi példájának alkalmazhatósága a Balaton és a magyar jog viszonyrendszerében. Pro Futuro, 2018/2, 9-23; SZILÁGYı János Ede: Vízszemléletü kormányzás - vízpolitika - vízjog, kitekintéssel a vízgazdálkodásra és víztudományra. Miskolci Egyetemi Kiadó, Miskolc, 2018, 231-232.

128 Wood: i. m., 126-129.

129 De Witt-de Boer-Hedlund-OsseweiJer: i. m., 101; BÁnyal Orsolya-Fodor László: Zöld jelzést kapott? Termékjelölések a fogyasztó- és a környezetvédelemben. In: Szikora Veronika-Árva Zsuzsanna (szerk.): A fogyasztók védelmének új irányai és kihívásai. DE ÁJK, Debrecen, 2018, 275-295. 
Ennek áldását, mintegy pozitív mellékhatásként, az egész földi ökoszisztéma élvezhetné. A jelenleg hatályos jogrendszereinknek tükrözniük kellene az „Örök rendet”, ha a cél az, hogy harmóniában éljünk emberekkel és természettel egyaránt.

\section{Abstract}

The article first of all holds that environmental regulation has failed. This is because it is too weak to prevent the overstepping of ecological boundaries by humanity. This legal regulation reflects that human behavior is psychopathological. This collective mental illness may originate from false self-identification. Therefore, the author reviews the outcomes of modern natural sciences, such as quantum physics, cosmology, and non-local consciousness research. These results give sufficient support to argue, despite the traditional paradigm of materialism, that some aspects of consciousness are not limited by the space-time continuum. Moreover, all consciousness, regardless of its physical manifestations, is part of the universal Consciousness. From these scientific results, in line with ancient scriptures, an Eternal Order has evolved, which can be described at least by four fundamental and universal truths. This Eternal Order should be taken into account by positive law, if humanity wants to reach fulfillment within the ecological limits of the Earth. 